\title{
Online Learning amidst Global Pandemic: EFL Students' Challenges, Suggestions, and Needed Materials
}

\author{
Novrika Nartiningrum \\ University of Muhammadiyah Malang, Indonesia \\ nnovrika@gmail.com \\ Arif Nugroho \\ IAIN Surakarta, Indonesia \\ arif.nugroho@iain-surakarta.ac.id
}

\begin{abstract}
Covid-19 pandemic brings changes in many aspects of peoples' lives throughout the world. The spread of Covid-19 in Indonesia affects the education system in this country. Face-to-face instructions are shifted into full online learnings from home. Despite this quite drastic change, the literature on students' insights of this matter has still been silent. Thus, the present study elucidates 45 EFL students' challenges, suggestions and needed materials during these online classes. Rely on qualitative data analysis from written responses and semi-structured interviews, the findings disclosed that these EFL students' main challenges in attending online courses were the unsteady networks and the less direct interactions. These students mainly suggested the use of video conferencing applications such as zoom or Google meet, though some students chose assignments over those applications. The students also mentioned that they basically needed grammar related materials within the online classes. The findings bring forward the picture of full online learning condition during Covid-19 outbreak on EFL setting in Indonesia.
\end{abstract}

Keywords: online learning, challenges, suggestions

\section{INTRODUCTION}

EFL teaching and learning process has been around for years. The media used in English as Foreign Language classes has evolved in some countries, along with the development of technology. Some face to face 
classrooms are slowly progressing into online classes (Lee \& Lee, 2019; Nugroho \& Mutiaraningrum, 2020). Some previous studies have discussed this shift in various countries. Ja'ashan (2015), for instance, investigated students' perception and attitudes on blended learning for English courses. In the blended learning, 20\% until $75 \%$ of the course content was delivered online. Through a questionnaire employed in his study, it was concluded that students' perception and attitudes towards blended learning were positive in general.

In response to the pandemic of Covid-19 in the beginning of 2020, Indonesia is one of many countries which tries out the implementation of EFL online classes. The application of online classes was decided nationwide in Indonesia since the education policy makers decided to apply a rule to change the offline classes into online classes in midMarch, 2020. This decision was taken following the Covid-19 outbreak. This pandemic forced the education ministry to propose online classes for schools and universities. At first, schools and universities were encouraged to alter the conventional classes into online classes for fourteen days.

Afterwards, all schools and universities were suggested to turn the offline classes into online ones for longer period of time. Some universities even decided to do the online classes for the rest of the semester. This quite sudden decision results in various reactions from both teachers and students. In relation to this, a study done by AlMunawwarah (2015) discussed teacher's perception on the use of ICT (information and communication technologies) in Indonesian EFL class. She found out three benefits of using ICT in EFL class; namely, helping teachers to conduct interesting and fun learning activities, promoting autonomy learning, and motivating students to learn. ICT can makes students active in the classroom (Apriani, 2019).

English language learning practices have been shifting from face to face classes to digital or online classes. This difference in method sparks questions about students' and teachers' perceptions toward the new system (Atmojo \& Nugroho, 2020). In general, studies examining the efficacy of the use of Information, Communication, and Technology (ICT) 
in EFL contexts have been conducted for years. A previous study done by Ashrafzadeh and Sayadian (2015) investigated university instructors' concerns and perceptions of technology integration. The data in this study were collected through a questionnaire followed by a semistructured interview. It was discovered that the sources of the instructors' concerns are administrative facilities, instructors' technology literacy toward technology integration and accessibility of technology for all students which are still lacking. Some studies were also investigating the attitudes toward technology use from students' point of view (Baz, 2016; Sabti \& Chaichan, 2014).

Sabti and Chaichan (2014) showed difference attitudes toward the use of computer technologies in learning English. While female students gave positive attitudes towards the use of computer technologies in learning English, male students expressed less positive attitudes toward it. However, both male and female students demonstrated positive perception of usefulness perceived ease of use of computer technologies in English learning processes. In the same opinion, Apriani (2016), ICT brings effects to many aspects of life including in education. ICT is not only improve students' English ability but also their character (Apriani, 2019). Similar study done by Baz (2016) that investigated the attitudes of EFL students and teachers towards the use of technology in language teaching and learning. The findings in this research indicated that students and teachers had highly positive attitudes towards the use of technology.

More recently, ELT practitioners have recently begun investigating the efficacy of learning English beyond classroom by means of accessible digital technologies. Lee (2019) examined the influence of informal digital learning of English (IDLE) activities beyond classroom toward a group of EFL students' vocabulary outcomes. This study found that the quality of IDLE activities was significantly and positively associated with the students' vocabulary outcomes. This result leads to the conclusion that engagement with varied types of IDLE activities is essential for language vocabulary acquisition. Furthermore, in terms of using digital devices for language learning, a study conducted by Lam, Hew, and Chiu 
(2018) revealed that online Edmodo discussion could enhance EFL students' writing on argumentative essay. This result implicates that as far as digital technologies are used appropriately, they can be alternative media to assist EFL students' language development.

In a similar direction, Kirovska-Simjanoska (2019) examined EFL students' preferences over the learning models. The results indicated that they valued the teacher's presence in the classroom and the social interaction. However, the students also considered online activities as effective and efficient ways in learning course content. With regards to the effectiveness of digital technology for language learning, a study conducted by Nugroho and Rahmawati (2020) proved that social networking site (e.g. mobile application Instagram) was recognized as an efficient tool to enhance students' writing skills.

Drawing on the pre-experimental design, their study further depicted that there was a significant difference on the students' writing scores between the pre-test and post-test. This result implies the potential use of digital technologies for language learning both inside classroom and outside classroom.

Recent research that investigate about online learning during Covid-19 has been done in various regions. One study done by Bailey and Lee (2020) discuss about the advantages, challenges and strategies in online teaching. From 43 native English speakers who teach EFL in South Korea, it was revealed that instructors with experience in teaching online expect fewer challenges compared to instructors with no online teaching experience. Thus, instructors with no online teaching experience were advised to start with LMS discussion forums and closed-ended quizzes.

A study related to online teaching during the pandemic in Indonesian setting was done by Atmojo and Nugroho (2020). The study investigated the teaching activities and challenges in secondary schools during the pandemic. Some challenges found were; some students did not have their own smartphone, the internet connection was unstable, some students were not able to afford sufficient internet quota, many 
students have low digital literacy and some students were not punctual in attending online classes.

These previous researches have given information on students', teachers' or both perceptions toward English online learning. However, the implementation of digital learning in those researches happened naturally (along with the development of technology and internet). On the other side, nationwide online learning in Indonesia was quite sudden and unplanned. The decision to implement national online learning was caused by Covid-19 pandemic that affected education system in Indonesia.

Furthermore, previous research related to online learning during Covid-19 pandemic often focused on teachers' perspectives and experiences. Thus, the present study offers perspectives and experiences from students, especially university students who are expected to have higher digital literacy compared to students from lower levels of education.

Initially, the online learning was intended for fourteen days only, but it has been prolonged for few times because of the Covid-19 outbreak. As a result, universities in Indonesia implemented full online classes. Considering the spread of the pandemic that yet to cease, universities work hard in adjusting their teaching and learning activities. Online platforms such as Google classroom and learning websites like canvas become more popular. Therefore, the present study is intrigued to examine the challenges and problems faced by Indonesian students in learning through virtual classrooms. Moreover, the present study also wants to explore students' suggestions and needs toward the unanticipated online learning in Indonesian EFL setting.

All in all, considering the present situation and previous researches, the present study intend to uncover the challenges, suggestions, and needs of EFL students in Indonesia towards the implementation of English online classes. Thus, in order to ensure the objectives, this study is guided by three research questions: (1) what kind of challenges experienced by Indonesian EFL students during 
online learning beyond classroom?, (2) what are students' suggestions toward the problems they have in online learning beyond classroom and (3) what do Indonesian EFL learners need in online learning beyond classroom?

\section{THEORITICAL FRAMEWORK}

Online learning or e learning refers to the use of digital tools for teaching and learning as mentioned by Arkorful and Abaidoo (2014). Technological tools are used to study anywhere and anytime. Online learning also involves training, delivery of knowledge and motivating students to interact with their friends. However, online learning in the present study is slightly different. Due to the spread of Covid-19 schools and universities in Indonesia are shifting the learning activities from face to face instructions into full online interactions so that the schedules are mostly fixed although students can join the class from all parts of Indonesia. The readiness of students and teachers in facing online learning is also varied due to the diverse practices of online learning and heterogeneous learning environment in Indonesia. Moreover, the sudden spread of the pandemic demands immediate implementation of full online learning so that sufficient amount of training cannot be covered.

Furthermore, Sun and Chen (2016) found that one of the essential challenges in online learning is to develop a sense of community in the online environment. Therefore, promoting social presence, interaction and collaboration is significant in the implementation of online learning. Thus, students and teachers have to make a joint effort to get deeply involved in encouraging collaboration and interaction between students and teachers also among students in order to create effective online learning communities. Considering that student-centered learning is the key in online learning, suitable means, approaches and technologies could be used to achieve the learning objectives.

Alongside the term online learning, there are similar terms such as e-learning (electronic learning), m-learning (mobile learning) and d- 
learning (digital learning). A study done by Basak, Wotto and Belanger (2018) shows the differences among the three terms. It is mentioned that e-learning involves communication through emails, happens in classroom or internet lab, uses fixed and private locations, is structured, more formal, and paced also needs time to travel to reach internet site. Meanwhile, m-learning uses instant messaging, can be synchronous or asynchronous, is self-paced, has no geographic boundaries and does not need travel time because it uses wireless internet connectivity. Elearning and m-learning are actually the subsets of d-learning which connects communities to a vast network of resources, is more flexible, owns style that maximizes success, consists exchanges with other learners, can access high quality and rigorous courses, also can be accessed anywhere and anytime since the time and location is independent.

Considering the differences among e-learning, m-learning and dlearning, it can be seen that the term online learning in the present study is rather the combination of those three terms. The online learning can use email and instant messaging in its activities. Although the locations are not fixed (can be accessed from anywhere), the time is mostly still dependent on the schedules from schools or universities. The learning processes are still formal and paced (not flexible) even though exchanges with other learners are mostly encouraged. Online learning can also be synchronous or asynchronous and the courses can have high quality if they are prepared well.

Moreover, in order to have effective online learning in higher education (HE) institutions, some recommendations were proposed by Ali (2020). The recommendations are: HE institutes need to have basic ICT infrastructure, teachers need ICT tools and must have access to applications and learning platforms, teachers must also be able to use the ICT tools effectively and teachers' and students' readiness must be supported accordingly.

Besides, it is observed that about $92 \%$ of all online studies online learning is believed to be at least as effective, if not better, than traditional learning according to Nguyen (2015). About 3\% of the 
studies compiled by the site show the opposite, that brick and mortar format is more effective, and about $4 \%$ show mixed findings. However, the repository is subject to selection issues due to voluntary submittal to the site.

\section{RESEARCH METHODOLOGY}

\section{Research Context and Participants}

This study is conducted in Indonesian context, particularly in teaching of English as foreign language of a private university in Malang Indonesia. A university in Malang was chosen considering that Malang was one of cities in Indonesia that became the destination of students from various regions in Indonesia to pursue further education. Thus, various backgrounds of students were expected to enrich the data obtained in the present study. The data were gathered in the age of covid-19 pandemic where Indonesian education system was moved from learning inside classroom in the schools or universities to online learning beyond the classroom. To examine the efficacy of the online learning by means of various digital technologies, 45 Indonesian EFL learners ( 7 male, 41 female) were purposively selected as participants based on a single and primary criteria that was amid the pandemic, they had experienced online learning by a range of digital devices. The participants were sophomore of EFL students of a private university in Malang Indonesia taking some language skill courses (e.g. speaking, writing, and reading). In the age of this pandemic, they carried out teaching and learning beyond classroom, but still under the guidance of their language instructors by utilizing digital technologies. Their age varied between 18 and 20, the average was 19 .

\section{Instruments}

A descriptive qualitative design was considered as an appropriate approach to delineate EFL learners' challenges, insights, and needs in response to examining the quality of language teaching and learning by using digital technologies during this pandemic. The descriptive qualitative is based on Yin (2015), that aims to reveal an in-depth 
understanding about a particular phenomenon, in this context, the efficacy of teaching English by means of technology from the views of EFL learners. To this end, written reflections and semi-structured interviews ere employed to elicit challenges, insights, and material needs of EFL learners in response to the technology-based learning activities beyond the classroom. Written reflection is a written story template consisting of a series of questions or/and instructions and blank spaces where participants write their responses (Barkhuizen, 2014). This kind of instrument enables the researchers to collect rich and deep description of data because the participants freely express their ideas and thoughts by writing them on the written reflection sheet. This lead to the accurate, enormous and wide range of obtained data since they have a lot of time and chance to voice their notion and beliefs (Hollweck, 2015). Moreover, semi-structured interview is used to seek a more detail understanding of the participants' responses stated in their written reflections. A semi-structured interview enables the researchers to come up with a new idea or question during the conversation in responding to the interviewee answers (Harding, 2018). The main benefit of this inquiry model is, as interviewer, the researchers have a structured guidance in hand, but still possible to broaden the guidance when it is necessary (Nugroho, Zamzami, \& Ukhrowiyah, 2020). Hence, written reflections and semi-structured interview were selected as instruments in this current study.

\section{Data Collection}

First, written reflections in form of web-based survey using Google form along with a set of questions and detail instructions to fill the reflections, was spread to about 92 EFL learners from two classes of English course by means of WhatsApp (the frequently used social media by Indonesian). After a number of weeks, 45 participants (named S1S45) returned their responses of list of questions in written reflections. 4 of the 45 participants (i.e. S2, S7, S20, and S23) were invited for semistructured interviews to follow up their interesting stories and description as written in their reflections, therefore the researchers recognized that they were worthy of further inquiry. The semi- 
structured interview was conducted individually by means of social media WhatsApp and last for about 55 minutes each. They were asked to explore their answers in the reflections as well as elaborate with examples and current issues about teaching English using digital technologies beyond the classroom.

\section{Data analysis}

For the sake of data analysis, the researchers carefully reviewed the data from both written reflections and semi-structured interviews. The researchers further analyzed and identified initial themes based on the three research questions of this study, i.e. EFL learners' challenges, insights and material needs. During the data coding, the researchers also removed the repeated and unnecessary data that extended beyond the themes. The researchers did the same analysis for the 45 written reflections from the participants until the saturation point was achieved. Saturation point is the point that shows no new information based on the emerging themes found during the data analysis. It happened when the researchers found similar data again and again. Therefore, saturation point is a clear indication of the end of data analysis (Poedjiastutie \& Rif'ah, 2019). Afterwards, the researchers compared, reviewed, and integrated the emerging themes from both written reflections and semi-structured interviews, which led to final data analysis and conclusion drawing. To ensure the validity and reliability of the instruments, the two researchers performed coding of the data from both written reflections and semi-structured interviews independently. It was then continued by stages of discussion to achieve the consensus on the final results.

\section{FINDINGS AND DISCUSSION}

\section{Findings}

This section uncovers students' responses on challenges they encountered during digital learning, suggestions they had for the betterment of the online learning and the materials that they needed in learning beyond classroom. The most representative responses both in 
written answers and semi-structured interview are quoted verbatim in order to assist the delineation of the findings. The findings interpretation and their relation to previous studies are further explained in the discussion section.

\section{EFL Students' Challenges amid the Online Learning}

Generally, students are having problems with unstable network connection. Participants mention that having bad signals or electricity blackout are problems that they have to face during the digital learning. For example, $\mathrm{P}_{15}$ shared her challenges in attending online class.

The problem that I face when online class is the internet network, if my package runs out, and also often lights out. the network that was suddenly cut off was very disturbing especially because I was living in a remote area, so finding a network was difficult, especially during the learning process or during the exam. often the internet network suddenly arrives and also hinders the process of gathering tasks and others. The problem with the data package here is that there is no WiFi network, so I only use the package, and also my package runs out here, many shops are closed because Covid 19, so finding credit sellers here is also difficult. (S15. written response)

Some students also expressed that in online learning, communications and social interactions between teacher and students or among students are lacking. This situation makes the students feel that their success in real life could be affected by the less opportunity of direct interactions.

The online lecture system does not require students to come face to face with the instructor directly. In the end, this method eliminates the opportunity to interact. Not only with lecturers, students also cannot socialize with other students. This is very crucial. The reason is the ability of social interaction greatly determines one's success in real life. Especially in the ESP course, 
which really requires direct social interaction in order to support the effectiveness of teaching and learning. (S12. written response)

Another problem faced by the students that is caused by lack of interactions is the less of feedback understood by the students. It leads to the feeling that the learning materials are more difficult to understand.

The problem is learning English language or ESP class without meeting face to face is very difficult to understand, lacks understanding of the material and also lacks an explanation of the incorrect or correct answers we write. (S7. Interview)

Few students honestly mentioned that online learning weakens their commitment in learning. Less control and guidance from the teacher make them lazier to learn. Students are more easily distracted when they are going to learn or doing the assignments.

The problem I faced during ESP online classes is that online classes can only provide less than the maximum guidance compared to when in class, online English classes do not provide face to face services. This has become a disadvantage as well as an obstacle. Guidance that is not face to face for some people will not be maximal. It is different if directly taught by a lecturer. I can pay attention to the lecturer's expression when saying words in English. So the articulation is more precise, online classes require the use of computers and other similar devices, this means that eye fatigue, poor posture and other physical problems can affect the learning process, with freedom of time and place, will make learning commitments weaker. There's always temptation. Like opening a game first before studying. Or online social media first before opening an English application. These temptations tend to loosen commitment. It will even be more important to play the game or its social media when compared to learning. My commitment if you want to succeed, I have to be more extra effort 
and more consistent to keep on learning and don't be lazy despite online classes (S2. Interview)

In brief, students' problems in digital learning are unstable networks that leads to lack of direct interactions. Minimum communications cause the learning materials become harder to understand. These situations contribute to students' weakening commitments to study. The students become easily distracted.

\section{EFL Students' Suggestions for Online Learning beyond Classroom}

After finding their challenges in facing digital learning, the students provided some suggestions in order to have more enjoyable online class. Though some suggestions contradict each other, most students proposed to use video conference applications such as zoom or google meet.

My suggestion in this online class is for esp-r, esp-w and esp$s$, to continue implementing online classes such as implementing classes in the zoom application or other applications to make it easier to interact. (S16. written response)

An interesting suggestion was given by S20. He wanted improvement in the online system such as making a special application for students.

Because in English courses, we also need discussion, there are 52 people in one class. If you have to stream it might not be optimal, because each person has different facilities, some have good and no connections, but so far there has not been a video call like that for discussion, my suggestion might be that in this course video video activities will be added to be discussed. or interactions between teachers and students because we students feel worried only to the extent of being afraid of not being able to get more effective teaching because not all material can be conveyed only 
via digital. Although the government's suggestion and the campus decision were correct about learning through online networks, my suggestion was to further improve the online durring system, such as a special application for students. (S20. Interview)

On the other hand, few students asked not to use face time. They asked for assignments and learning materials that can be downloaded.

I suggest for ESP online class to not doing online class with face time, because I think isn't effective for students who have problems with their connection network. Just give an assignment and material for doing online class. (S2. Interview)

Another most popular suggestion is asking the teacher to give clear deadlines for each assignments given. The students mentioned that deadlines help them to avoid laziness in doing the assignments.

I apologize very much for saying this before, the task given by the teacher should be given a deadline so that we all work on it immediately and get it collected immediately. During the online class we become unable to manage time and of course filled with other tasks. Then the teacher should give us a deadline so that the task can be quickly resolved and we avoid lavdis-20 (lazy virus desease 2020) thank you. (S44.written response)

Students also mentioned that they wanted fun learning activities such as watching movies, singing songs, doing quizzes or playing games.

My advice is to keep the condition of the class with relaxed lessons so that students can be more relaxed and easier to accept the lesson. Provide material in the form of games such as guessing words in English and other games so that students are not boring in class. Provide music with English songs in class with the volume not too loud so that students are accustomed to hearing sentences 
in English and their vocabulary will increase, it can also help students to remember material more easily. (S2. Interview)

\section{EFL Students' Material Needs for Online Learning}

Not only did the students give their suggestions, but they also mentioned some materials that they want to have in the digital learning. Most student agreed that they need materials related to grammar.

I really want to learn more about grammar. I want to be able to make sentences that are good and right. And I want to be more confident when speaking and practicing speaking as much as possible, because I really like English. (S6. written response)

Other than grammar, students wanted materials for enriching their vocabularies. The students want to know how to use correct vocabularies in sentences.

Some ESP learning materials that I want to get first are about using vocabulary and being able to understand the use of the right words in reading. My reason is, so my use of vocabulary can increase. (S3. written response)

Some students also mentioned that they want materials that are related to current problems in Indonesia. Students seem interested in Covid-19 phenomenon that has been spreading quite rapidly in Indonesia.

The material that I want to learn in ESP online class is COVID-19 which starts from the virus, the way it is spread, the conditions for patients who must be treated or independent isolation at home. COVID-19 is the reason why we changes in the learning system into an online system, as a student I want to invite the public, especially people we know to joint eradicate the corona virus, the material can be utilized on WHO, so I hope health students can become agents of change in eradicating COVID-19. (S23. Interview) 
Other students responded that they need materials that will be useful for their current education or for their future. Some students shared that they wanted to be able to write good reports and scientific journals.

I want to learn how to write scientific journals when study ESP. Writing scientific journals usually uses standard and formal language. Apart from that, as students, we usually get assignments to write journals, papers and other written works. (S45. written response)

While some students concerned in honing their skills related to their current study, some other students chose to get materials that will help them in getting jobs, such as how to make good CVs, how to answer questions in job interviews and how to get high scores in TOEFL tests.

I want to get any material that is in accordance with the ability TOEFL test. Because in my opinion the TOEFL test is very necessary. And hopefully in the future English class will focus on learning about TOEFL test (S24. written response)

Lastly, some students wanted not too difficult learning materials. They liked to have songs, games, comics or movies as their learning materials, especially for assignments.

The material that I need is reviewing a film that is not a film from Indonesia, where when the lecturer gives us the material, students will not only feel bored while doing the assignment but, students will also be able to develop their thoughts, to be able to understand the film they have watch it. Besides that by watching, we have honed 3 senses at once, namely the eyes, ears, and mouth. Thus the lecturer will not be difficult to be able to make students speak English. Or review a comic, where 
students will be able to read carefully and try to understand what they have read. (S2. Interview.

\section{Discussion}

The challenges that the students faced during digital learning are mostly related to network connections. Especially students who lived in remote areas told that it was difficult to have good and stable signals. A student even shared that there was no Wi-Fi network in her village, so she needed to buy internet package in stores. However, many shops were closed due to Covid-19. Therefore, it was more challenging for her to join online classes. This situation is actually expected since Indonesian archipelago consists of thousands of islands and the internet signals in every island are varied. This situation is similar to the findings in a study conducted by Mohalik and Sahoo (2020). Out of 318 student teachers participated in the study, only $25 \%$ of them who were having good internet connectivity.

The next problem was lack of effective direct interaction between students and teacher or among students. This situation led to less understanding of materials discussed in the online class. Again, this condition can also be caused by unstable internet connections. Different from circumstances in the classrooms that enable students to have direct interaction with their teacher, students communications with their peers and teacher in online classes depend heavily on the internet signal. Therefore, excellent internet connections becomes the main resource in online learning.

A student also expressed his opinion that minimum direct interaction might affect their success in real life. It actually makes sense since our daily lives are not a hundred percent happen online yet. Many working places, especially in Indonesia, still rely on direct interactions from person to person (Nugroho \& Atmojo, 2020; Suramto, 2019). Although some teachers have tried to add the experience of direct interaction by utilizing video conferences in their online classes, it still cannot substitute for the real-life communication since many problems such as unstable internet connection may hinder students from 
conveying their ideas effectively during language learning. Thus, these worries should be addressed seriously.

Another problem was about commitment in learning. This problem occurred since there were more temptations for not studying while joining online classes compared to when studying in offline classes. This is in line with a proposed study done by Kirovska-Simjanoska (2019) and Inderawati et al. (2019). They mentioned that the digital learning depended greatly on students' motivation. The learning process was dependent on distractions that the students faced when studying at home. Thus, low-motivated students should have more effort to keep themselves motivated by recalling their goals in learning the language. Meaningful but fun learning materials prepared by the teachers could also assist students with low motivation.

Suggestions proposed by students in the implementation of online learning is by using video conferencing applications such as zoom or google meet. The students believed by using these kinds of applications would give students more opportunity to have more interaction in online class. This suggestion is in agreement with a research done by Tanveer (2011). The study presented that out of 46 students, $82.4 \%$ students are in agreement that they prefer to learn from a teacher who utilizes various e-tools in teaching. Besides, this kind of synchronous learning might help students to comprehend the materials better since they could obtain faster response from the teacher through the verbal communication during the video conference.

Furthermore, a recent study done by Amin and Sundari (2020) was also in line with the suggestions proposed by students in the present study. Amin and Sundari found that student-participant agreed that WebEx Meeting video conferencing platform was beneficial for language learning. Some free video conferencing platforms such as WebEx Meeting, Zoom, Google Meet and Jitsi Meet can become solutions for the lack of direct interactions during the online learning.

A student even suggested the government or the university to make a special application for students in order to support the online 
learning. This suggestion could be a good way out from internet connection problem. Particular application that utilize specific internet access, apart from internet access for general public might be effective to overcome bad internet signals problems. However, further studies on this matter are clearly needed.

On the other hand, some students mentioned that they prefer doing assignments instead of joining face-to-face applications. This is in contrast with a study done by Alaidarous and Madini (2016). The study mentioned that students perceived their blended learning environment positively. In contrast, the student in the present study argued that using face-to-face application was not effective for learning due to unstable networks. This is in line with a study conducted by Alebaikan and Troudi (2010) which mentioned that blended learning programs are recommended to require only $25-50 \%$ of the course credit to originate from web-based instruction. The percentage is specified in order to preserve the value of face-to-face instruction.

Moreover, a study carried out by Al Zumor, Al Refaai, Eddin, and Al Rahman (2013) investigating the advantages, limitations and suggestions for blended learning stated that both students and instructors require appropriate orientation and training. The results of this study, however, indicated that sufficient training and orientation are probably quite difficult to be administered since the spread of Covid-19 limits people activities including education practitioners. Thus, the existing webinars for teachers are essential to provide guidance during the online learning. Universities could also arrange webinars for students in order to familiarize them with the Learning Management System owned by several universities in Indonesia.

As for the third research question, students also named learning materials they needed during the online learning. Most students answered that they need grammar materials. Other than grammar, many students wanted to get materials that can enrich their vocabularies. Materials related to newest issues such as Covid-19 were interesting for some students. Besides, students demanded learning 
materials that will be able to assist them during their study or to help the students for getting jobs. Similar to results reported by Polida (2017), some students aspired to be able to write good reports, get high score in TOEFL tests, make good CVs or experience a great job interview.

Furthermore, students also demanded not too difficult learning materials. Some students mentioned that they wanted to have songs, games, comics or movies as their learning materials or assignments. These requests are understandable considering students might get bored in studying online at home with limited direct interactions with their peers. Therefore, online games related to the subjects learned are suggested by Uukkivi and Labanova (2018). They believed that games could make learning more enjoyable and effective. Implementing games in online classes could be a challenge for the teachers, thus, teachers are encouraged to familiarize themselves with educational games websites such as quizziz.com in order to provide meaningful games for their students.

Students' request of materials that can enrich their vocabularies need to be addressed since a research done by Al-Jarf (2016) indicated that online instruction had an effect on vocabulary development. It was proven that online instruction was a powerful tool for improving students' vocabulary achievement. Online instruction also raised lowest-performing, average and good students' performance. Moreover, learning activities through digital devices apparently suit the twenty-first century learners who are well-known as digital native generation (Nartiningrum \& Nugroho).

Additionally, since some students aspired to get high score in TOEFL, including online TOEFL preparation program as learning materials could be considered. A study conducted by Sudrajat and Astuti (2018) proved that TOEFL test preparation program was able to improve performance in structures and written expression test of TOEFL. Furthermore, the majority of the students in the study agreed that they felt more confident to master English grammar after taking part in TOEFL preparation online course. 
The present study has some implications for the effective online learning amid Covid-19 outbreaks. First, the results give insights from EFL learners about the challenges they have in sudden full online learning implementation. Network problem was the biggest challenge for the students who already went back to their homes. This is in line with a recent study conducted by Adnan and Anwar (2020) who found that some students $(17.5 \%)$ still have limited access to internet and a few of them $(9.5 \%)$ reported that they have no proper access to the internet. Furthermore, (51.6\%) students reported that the major problem causing limited internet access is signals availability/strength. Second, suggestions from the students and information about their learning materials needed by students can be found in the present study. Therefore, the online teaching and learning processes can run more effectively by considering the mentioned inputs from the students.

\section{CONCLUSION}

The findings in the present study offers insights from EFL students about the implementation of online learning beyond classroom. Students shared their challenges in attending online learning classes. Unstable network, lessened social interaction that caused less understood materials and weakened commitment in learning are challenges faced by students during online courses in Covid-19 era. Some suggestions proposed by the students to overcome the challenges are the use of video conferencing applications such as zoom or Google meet, the development of a special application for students, the given deadline and the existence of fun learning activities. Moreover, most students considered that they needed grammar related materials. Many students also demanded materials that would enrich their vocabularies. Also, some students responded that they wanted to be able to write good scientific reports. They also needed materials that would enable them to make good CVs, get high scores in TOEFL and have great answers for job interviews. Materials related to current problems were interesting for the students. 


\section{REFERENCES}

Adnan, M. \& Anwar, K. (2020). Online Learning amid the COVID-19 Pandemic: Students Perspectives. Journal of Pedagogical Sociology and Psychology, 2(1), 45-51.

Al-Jarf, R. (2016). Teaching Vocabulary to EFL College Students Online. CALL-EJ Online, 8(2), 1-16.

Al-Munawwarah, S. F. (2015). Teachers' Perceptions on the Use f ICT in Indonesian EFL Learning Context. English Review: Journal of English Education, 3(1), 70-80.

Al Zumor, A. W. Q., Al Refaai, I. K., Eddin, E. A. B., \& Al-Rahman, F. H. A. (2013). EFL Students' Perceptions of a Blended Learning Environment: Advantages, Limitations and Suggestions for Improvement. English Language Teaching, 6(10), 95-110.

Alaidarous, K., \& Madini, A. A. (2016). Exploring EFL students' perception in blended learning environment in Saudi technical education context. International Journal of Educational Investigations, 3(6), 69-81.

Alebaikan, R., \& Troudi, S. (2010). Blended learning in Saudi universities: challenges and perspectives. ALT-J, 18(1), 49-59.

Ali, W. (2020). Online and Remotes Learning in Higher Education Institutes: A Necessity in Linght of Covid-19 Pandemic. Higher Education Studies, 10(3), 16-25.

Amin, F. M., \& Sundari, H. (2020). EFL students' preferences on digital platforms during emergency remote teaching: Video Conference, LMS, or Messenger Application? Studies in English Language and Education, 7(2), 362-378. doi.org/10.24815/siele.v7i2.16929.

Apriani, E. (2016). A New Literacy: The role of technology to develop student's character. Ta'dib: Journal of Islamic Education Uurnal Pendidikan Islam), 21(1), 59-72.

Apriani, E., \& Hidayah, J. (2019). The ICT Used by the English Lecturers 
for Non-English Study Program Students at IAIN Curup.Vision: Journal for Language and Foreign Language Learning, 8(1), 26-37.

Apriani, E., Supardan, D., Sartika, E., Suparjo, S., \& Hakim, I. N. (2019). UTILIZING ICT TO DEVELOP STUDENT'S LANGUAGE ETHIC AT ISLAMIC UNIVERSITY. POTENSIA: Jurnal Kependidikan Islam, 5(1), $1-14$.

Arkoful, V. \& Abaido, N. (2014). The role of e-learning, the advantages and disadvantages of its adoption in higher education. International Journal of Education and Research, 2(12), 397-410.

Ashrafzadeh, A., \& Sayadian, S. (2015). University instructors' concerns and perceptions of technology integration. Computers in Human Behavior, 49, 62-73.

Atmojo, A. E. P. \& Nugroho, A. (2020). EFL Classes Must Go Online! Teaching Activities and Challenges during COVID-19 Pandemic in Indonesia. Register Journal, 13(1), 49-76. doi: 10.18326/rgt.v13i1.49-76.

Bailey, D. R. \& Lee, K. R. (2020). Learning from Experience in the Midst of Covid-19: Benefits, Challenges, and Strategies in Online Teaching. Computer-Assisted Language Learning Electronic Journal, 21(2), 178-198.

Barkhuizen, G. (2014). Revisiting narrative frames: An instrument for investigating language teaching and learning. System, 47, 12-27.

Basak, S. K., Wotto, M., \& Belanger, P. (2018). E-learning, M-learningand D-learning: Conceptual Definition and Comparative Analysis. ELearning and Digital Media, 15(4), 191-216. DOI: 10.117/2042753018785180.

Baz, E. H. (2016). Attitudes of Turkish EFL Student Teachers towards Technology Use. Turkish Online Journal of Educational TechnologyTOJET, 15(2), 1-10.

Harding, J. (2018). Qualitative data analysis: From start to finish. SAGE Publications Limited. 
Hollweck, T. (2015). Robert K. Yin.(2014). Case Study Research Design and Methods. Thousand Oaks, CA: Sage. 282 pages. Canadian Journal of Program Evaluation, 30(1).

Inderawati, R., Sofendi, Purnomo, E. M., Vianty, M., Suhendi, D. (2019). Students Engagement in Utilizing Technology for Learning Support. English Franca: Academic Journal of English Language Education, 3(1), 182-196. dx.doi.org/10.29240/ef.v3i02.1111

Ja'ashan, M. M. N. H. (2015). Perceptions and Attitudes Towards Blended Learning for English Courses: A Case Study of Students at University of Bisha. English Language Teaching, 8(9), 40-50.

Kirovska-Simjanoska, D. (2019). Digital vs in-Person Learning Environment in ESP Classrooms: Let the Students Decide. SEEU Review, 14(1), 36-68.

Lam, Y. W., Hew, K. F., \& Chiu, K. F. (2018). Improving argumentative writing: Effects of a blended learning approach and gamification. ELT Journal, 22(1), 97-118.

Lee, J. S. (2019). Informal digital learning of English and second language vocabulary outcomes: Can quantity conquer quality? British Journal $\begin{array}{llll}\text { of } & \text { Educational Technology, 50(2), }\end{array}$ https://doi.org/10.1111/bjet.12599

Lee, J. S., \& Lee, K. (2019). Informal digital learning of English and English as an international language: The path less traveled. British Journal of Educational Technology, 50(3), 1447-1461. https://doi.org/10.1111/bjet.12652

Nartiningrum, N. \& Nugroho, A. (2020). Classroom Activities for Teaching Speaking: Voices of Indonesian EFL Learners. Jurnal Pendidikan Bahasa, 9(1), 35-46. doi.10.31571/bahasa.v9i1.1689

Nguyen, T. (2015). The Effectiveness of Online Learning: Beyond No Significant Differences and Future Horizons. MERLOT Journal of Online Learning and Teaching, 11(2), 309-319.

Nugroho, A., \& Rahmawati, A. (2020). "Let's Write A Caption!": Utilizing 
Instagram to Enhance ESP Students' Writing Skills, JURNAL BASIS, 7(1), 1-12. https://doi.org/10.33884/basisupb.v7i1.1782

Nugroho, A., Zamzami, M. R. A., \& Ukhrowiyah, N. F. (2020). Language input, learning environment, and motivation of a successful EFL learner. Journal on English as a Foreign Language ( JEFL ), 10(1), 46-69. https://doi.org/10.23971/jefl.v10i1.1511

Nugroho, A. \& Mutiaraningrum, I. (2020). EFL teachers' beliefs and practices about digital learning of English. Edulite: Journal of English Education, Literature, and Culture, 5(2), 304-321. https:// doi.org/10.30659/e.5.2.304-321

Nugroho, A. \& Atmojo, A. E. P. (2020). Digital learning of English beyond classroom: EFL learners' perception and teaching activities. Journal of English Education and Linguistics Studies, 7(2), 219-243. https://doi.org/10.30762/jeels.v7i2.1993

Poedjiastutie, D., Rif'ah Lailatul (2019). English Communication Needs of Engineering Students. International Journal of Language and Linguistics, 7(2), 69. https://doi.org/10.11648/j.ijll.20190702.13

Polida, Y. (2017). Peer Review: A Stretegy to Improve Students' Academic Essay Writings. English Franca: Academic Journal of English Language and Education, 1(1), 45-60. http://dx.doi.org/10.29240/ef.v1i1.157

Sabti, A. A., \& Chaichan, R. S. (2014). Saudi high school students' attitudes and barriers toward the use of computer technologies in learning English. SpringerPlus, 3(1), 1-8.

Sudrajat, W. N. A., \& Astuti, E. R. (2018) Students' Perceptions of the Use of TOEFL Preparation Online Course on the Test Perforrmance: the Case of TOEFL Structure and Written Expression Test. HUMANIORA, $9(3), 275-282$.

Sun, A., \& Chen, X. (2016). Online education and its effective practice: A research review. Journal of Information Technology Education: Research, 15, 157-190. 
Suramto. (2019). Developing the Students' English Listening Skill by Applying Drama Movies Viewing Techniques. English Franca: Academic Journal of English Language Education, 3(1), 97-108. http://dx.doi.org/10.29240/ef.v3i01.819

Tanveer, M. (2011). Integrating E-learning in Classroom-based Language Teaching: Perceptions, Challenges and Strategies. ... Conference "ICT for Language Learning." http://conference.pixelonline.net/ICT4LL2011

Uukkivi, A., \& Labanova, O. (2017). E-learning materials, methods and tools to activate students. New learning scenarios in digitalized world: international workshop, page 31-39.

Yin, R. K. (2015). Qualitative research from start to finish. Guilford publications. 